
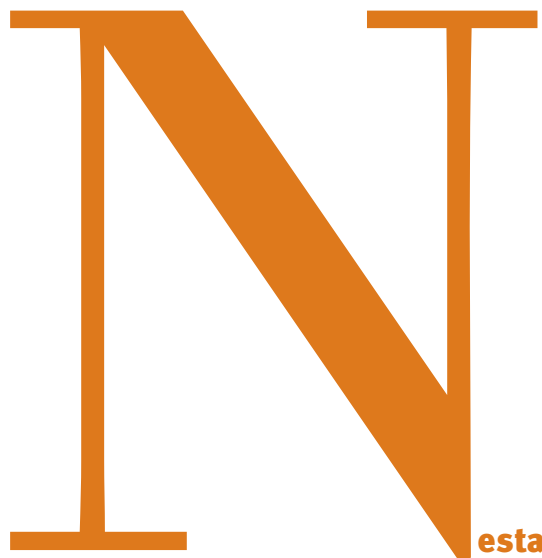

minar um ciclo esquecido: a segunda etapa do ensino fundamental, $5^{\underline{a}}$ a $8^{\underline{a}}$ séries (ou $6^{\underline{a}}$ a $9^{\underline{a}}$ ), freqüentada por mais de 15 milhões de alunos brasileiros. Para isso, o Cenpec realizou um cuidadoso estudo em nível nacional para conhecer melhor essa problemática, refletir sobre ela e apontar caminhos para resolver alguns problemas.

Para além de um decálogo de faltas e fragilidades, o estudo realizado pelo CENPEC dialoga com as complexas características do Ciclo II, que guarda algumas características:

- Ensino organizado num conjunto de disciplinas ministradas por professores especialistas que partem da suposição de que o aluno já tenha se alfabetizado e adquirido trânsito mais competente na leitura e escrita, assim como maior autonomia para aquisição de novos conhecimentos e competências.

- Ensino direcionado a pré-adolescentes e adolescentes.

- Ensino majoritariamente gerido pela esfera de governo estadual, enquanto o primeiro ciclo já se encontra municipalizado.

Percorrendo o território de $5^{\underline{a}}$ a $8^{\underline{a}}$ séries, dois foram os eixos escolhidos pelo olhar dos pesquisadores:

- a função social da escola e o papel da leitura;

- a produção textual nas diferentes disciplinas.

Na busca de ampliar o debate, convidamos vários especialistas para adensar a temática central deste caderno. Assim, da fragilidade da autoridade docente à indisciplina dos alunos até as experiências positivas de universalização com melhoria da aprendizagem - caso do Acre e de Goiás -, vários retratos são apresentados.

\section{Um ciclo pouco estudado}

Em alguns deles, podemos perceber que, quando a realidade impõe um limite, dele mesmo brotam as experiências mais inovadoras, como aquelas que interligam a escola a outros programas locais, numa teia de aprendizagens que alavanca a inclusão social.

A universalização do acesso ao ensino fundamental está praticamente atingida. Em relação aos indicadores de qualidade e eqüidade, ainda estamos distantes dos padrões desejados e necessários ao desenvolvimento nacional.

Cada vez mais, um maior número de crianças e adolescentes pobres tem acesso à escola; porém, eles estão aprendendo menos e nem sempre conseguem terminar os estudos básicos.

Agora é a qualidade da educação em nosso País que assume um sentido de urgência democrática, pois precisamos de uma escola de boa qualidade para todos, apoiada numa política educacional compromissada e abrangente, que diminua as desigualdades regionais na educação.

Socializamos neste caderno diversas reflexões referentes ao segundo ciclo do ensino fundamental, pois há uma enorme demanda por dar lhe vez e voz na agenda de prioridades da educação básica.

Esperamos contribuir para que educadores e secretarias de educação que atuam no Ciclo II do Ensino Fundamental se sintam estimulados a inovar, garantindo uma educação de qualidade para todos.

Maria Alice Setubal

Diretora Presidente do CENPEC 